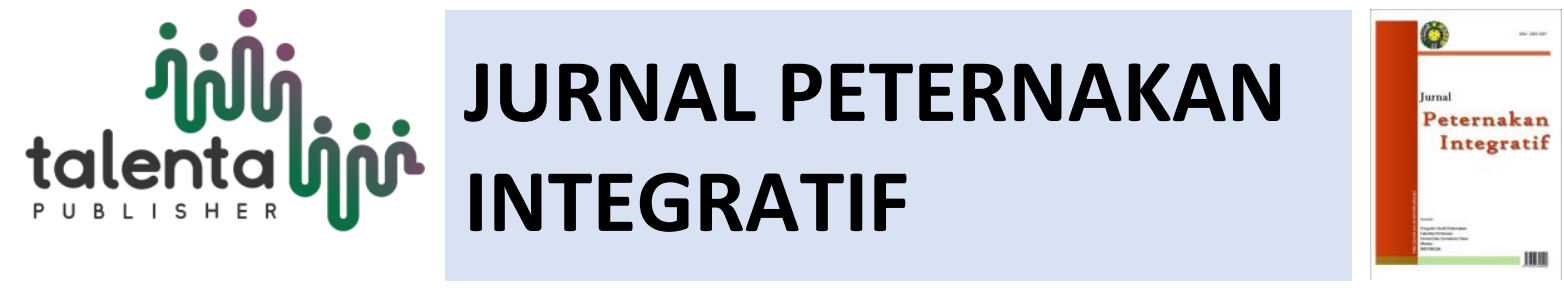

\title{
Developing Feeding System and Tecnology Innovation for Intensive and Export-Oriented Goat Production
}

\author{
S.Ginting ${ }^{1}$ \\ ${ }^{l}$ Goat Research Centre Sei Putih, Galang, Sumatera Utara, Indonesia
}

\begin{abstract}
There is large potential for exporting meat goats and so gaining more economic benefit from raising this animal. There are several constraints faced by the goat producers or traders in fulfilling the potential demand of the market. Developing a more intensive goat production system is urgently needed in order to increase the capacity of the stock supply while at the same time the goat population is developing to make the system sustainable in the long term.

In intensive goat production system feed play a central component in achieving the maximum economic efficiency of the production, since under such production system the feed could contributed up to $70 \%$ of the total production cost. To reach a high efficiency in feed utilization for goat production system there are at least two feeding system that could be considered. Feeding system and feed management is aldo critical to be developed intensively to be more well adaptive. Feed budget or feeding standard are some alternative feeding approach for intensive goat production system and feeding strategy and feed technology are important in optimizing the level of productivity of goats during each phase of its life cycle and production.
\end{abstract}

Keywords : Goat Production, Feeding System, Intensive, Cost Benefit, Feed Budget

Received [19 November 2019]| Revised [10 December 2019]|Accepted [31 December 2019]

\section{Introductions}

Exporting the agriculture commodities is currently strongly promoted by the Indonesian government to gain more value added. Goats is one of among other food animals that has been considered to be a potential export commodity [2]. Although exporting live goat and sheep in particular to Malaysia has been in progress recently, this economic activity has been proceeding sporadically. The adequacy of continuous supply of animal stocks with specific qualities required by the importer country is an crucial element in this supply chain [19]. The dominancy of the smallholder type system of goat production in Indonesia with small operation scale, large variation in animal quality and highly-scatterd geographical distribution make the supply of live goats difficult to consolidate. Other constrain is the available breed type of goat which is dominated by Kacang goat and its crossbeds having relatively low body weight and 


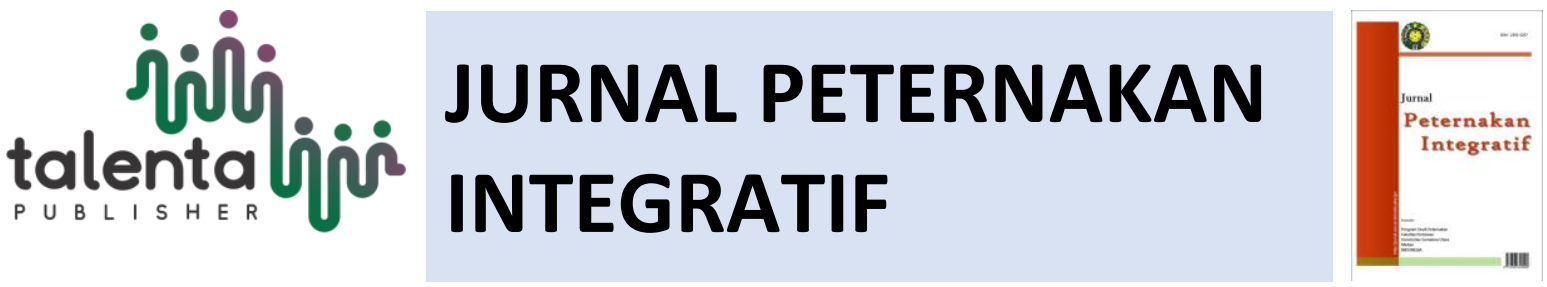

growth rate. Boerka goat, a new goat breed with better growing and body weight capacity provide a prospect alternative type of meat goat for export purpose.

It is important to realize that a competitive and improved goat production system should be developed in order to maintain a continuous supply of live goats with good quality. The production system should be able to keep the national goat population and quality to be dynamically sustaninable in the long term. To achieve this purposes the type of production and management should be adapted accordingly. Among other management aspects in goat production system the feed and feeding system play a crucial role, since it is the largest contributor to the total production cost and biologically the most determinator of production level. This paper describe alternative feeding systems that might be implemented in intensive goat production system. Recent technological innovation that potentially adopted in various physiological state goat production cycle is discussed.

\section{Feeding System Approach for Intensie Goat Production}

In intensive goat production system feed play a central component in achieving the maximum economic efficiency of the production, since under such production system the feed could contributed up to $70 \%$ of the total production cost. To reach a high efficiency in feed utilization for goat production system there are at least two feeding system that could be considered (Figure 1). The feed budget approach put the potential of feed available as the limiting factor for reaching the optimum level of production parameters. Thus, under this feeding system the target is how to maximize the potential and efficiency of utilization of available feeds. The target of production (animal genetic potential) is therefore compromised.

Feed Suply (Feed Budget Approach)

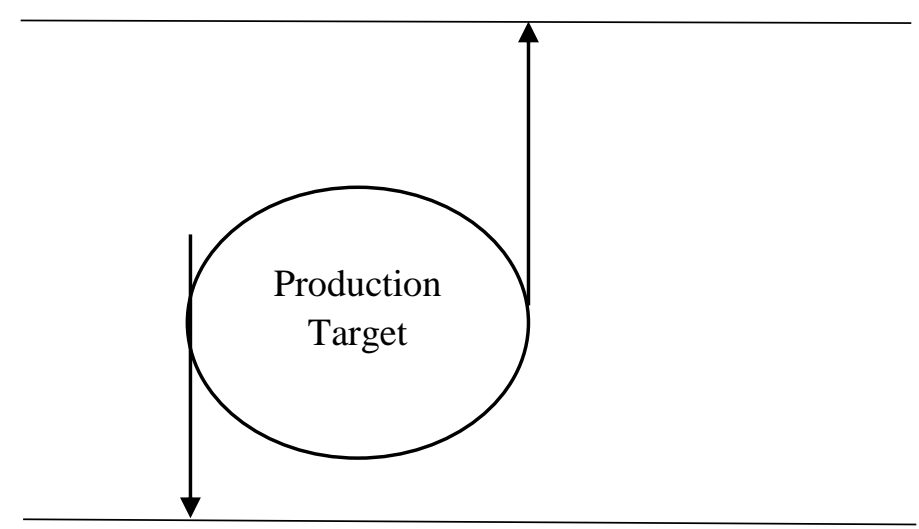




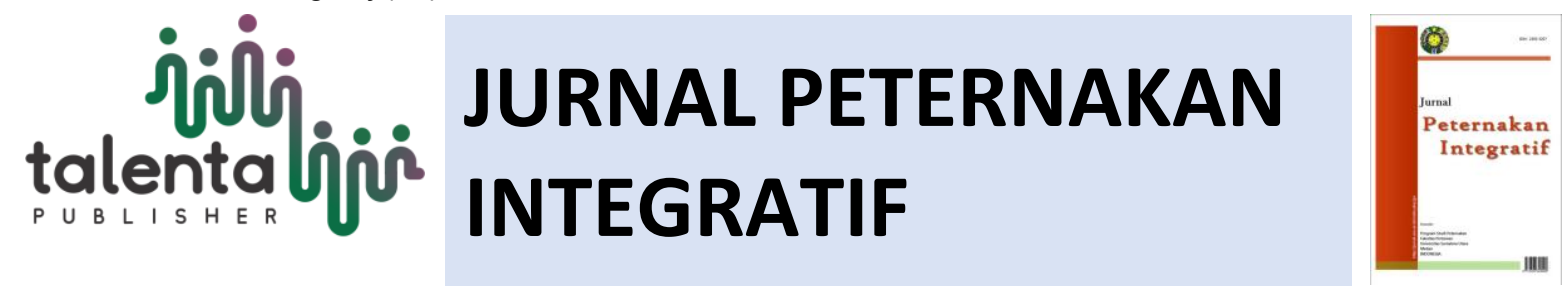

Genetic Potential (Feeding Standard Approach)

Figure 1. Feeding system based on the feed suply (feed budget) and on the animal genetic potential (feeding standard

In the feed budget approach the basis of feed is developed and managed based on the maximum potential of available feed that could be obtained from a production system. The feed types could be forages, roughage or agroindustral by-product and plant residues. The feed budget should be linked to the its seasonal availability. In this case, a feed calender would be important to develop so that the countinuity of the feed is guaranteed by anticipating when there might be surplus or shortage of the feed during a certain period of time. Increasing the nutritional potential of available feed could be achieved through the implementation of appropriate or specific feed technology. The nutritional and availability capacity of the feed could be improve by: (1) utilization of new feed ingredient, (2) correcting the improper technological use, and (3) improving the efficiency of available feed utilization. The pattern of the fluctuation of the feed should be predicted tactically for less fluctuated or strategically for more fluctuated feed (Bell, 2009). The feed budget system would be more applicable in a less intensive production system where feed will mostly consist of locally available feed ingredients such as agroindustrial by products and/or plant residues. Many of such feed ingredients are able to support a moderate to high levels of production when used efficiently in different agro-ecosystem (Table 1). Feed technology such as total-meixed ration and ensiling could be adopted to improve the efficiency of feed utilization in the palm oil-goat production system where fibrous feed such as palm oil frond and palm pressed fibre and concentrate feed such as palm kernel cake and palm oil mill effluent are abundantly available. In the horticulture-goat production system there is potential of horticulture by products as the source feed. In addition, feed availability and utilization may be increased through the introduction of appropriate grass and leguminous species. Calliandra callothyrsus is a potential leguminous tree to be developed in the high land of agricultural. As the tannin content in this leguminous tree is relatively high that might reduce its palatability for goat other leguminous trees such as Indigifera zollingeriana could be introduced to complement the calliandra callothyrsus as protein supplement. Ensiling technology would be appropriate to conserved the horticulture by products or residues for used as goat feeds which production and availability are usually seasonal. In the food crop-goat production system most feed are of the fibrous 


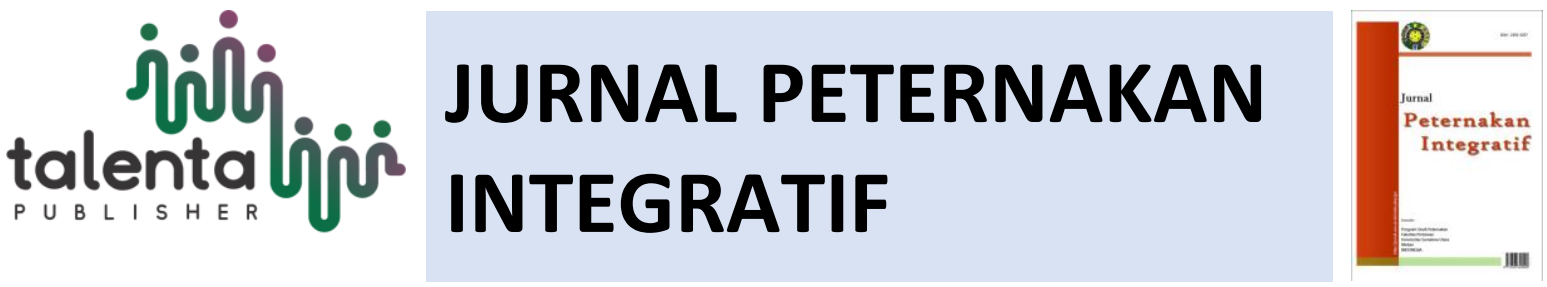

type with low intake and digestibility. The improve the nutritional value of such feed ingredient ammoniation and bio-conversion process could be alternative for consideration. Since the protein content of the fibrous feed is typically low, the strategic supplementation should improve the nutritional quality of these feed.

Table 1. Implementation of the feed budget approach in several agro-ecosystem for goat production

\begin{tabular}{|c|c|c|}
\hline Production system & Feed type & Feed technology \\
\hline Palm oil-goat system & $\begin{array}{l}\text { Fibrous and concentrate feed } \\
\text { and forages }\end{array}$ & $\begin{array}{ll}\text { - } & \text { Total mixed ration } \\
\text { - } & \text { Ensiling } \\
\text { - } & \text { Strategic supplementation }\end{array}$ \\
\hline Horticulture-goat system & Fibrous feed and forages & $\begin{array}{ll}\text { - } & \text { Ensiling } \\
\text { - } & \text { Strategic supplementatiom }\end{array}$ \\
\hline Food crop-goat system & Fibrous feed forages & $\begin{array}{ll}\text { - } & \text { Ammoniation } \\
\text { - } & \text { Bio-conversion } \\
\text { - } & \text { Strategic supplementation }\end{array}$ \\
\hline Grazing system & Forages & $\begin{array}{ll}\text { - } & \text { Rotational grazing } \\
\text { - } & \text { Introducing grass species } \\
\text { - } & \text { Introducing legume species } \\
\text { - } & \text { Internal parasite control }\end{array}$ \\
\hline
\end{tabular}

Where there is vast grazing area goats could be raised under intensive grazing system by applying the rotational grazing and introducing grass species with higher productivity. Grass species such Brachiaria ruziziensis is a good altertnative to develop in the open grazing area where Stenotaphrum secundatum is a shade tolerant grass species so that it will fit for the plantation area. Leguminous species sech as Indigofera zollingeriana, Leucaena leucocephala could be introduced in border land and used as as green concentrate supplement. I. zollingeriana will be suited in the area with more acidic soils while the L.leucocephla is less suited in the acidic soil and so should be developed in the area of non acidic soils. 


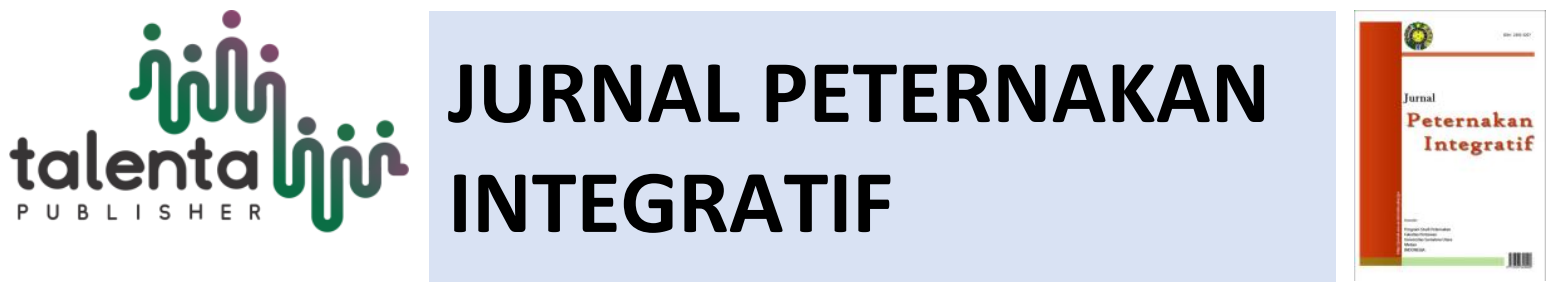

- Alternative to the feed budget approach is the feeding standard system. In this feeding approach feed is assumed not to be a limiting factor, but the animal genetic capacity is the limiting facor. Feeding standard system allocate feed ingredient to meet the standard requirement of the animal. There three main component of the feeding standard system i.e. the animal (genetic potential), the feed and the agroecosystem . The feeding standard system would be more fit to the high input system and accurate information about the nutritional characteristics and animal requirements on the various nutrients under certain physiological state are essential. Ideally, any feeding system should be responsive and predictive in nature so the mechanistic and deterministic medelling approach is important, although under practical situation the less dynamic model are more relevant. Some figures on metabolizable enenrgi and protein (digestible and crude) requirement of goat at several physiological state recently published is presented in Table 2.

Table 2. Energy and protein recoomendation for goat in feeding standard system

\begin{tabular}{lccc}
\hline \multicolumn{1}{c}{ Physiological state } & Metabolisable energy & Digestible Protein & Crude Protein \\
\hline Growing & $104-108 \mathrm{Kcal} / \mathrm{BW} 0.75^{\mathrm{ab}}$ & $0.446 \mathrm{~g} / \mathrm{kg} \mathrm{Gain}^{\mathrm{b}}$ & - \\
& $116 \mathrm{Kcal} / \mathrm{BW} 0.75^{\mathrm{c}}$ & - & -
\end{tabular}

Gestation

Whole Lactation $1166 \mathrm{Kcal} / \mathrm{kg} \mathrm{milk}^{\mathrm{d}} \quad 1.45 \mathrm{~g} / \mathrm{g} \mathrm{milk}$

Early lactation (1-4 wk) $2700 \mathrm{Kcal} / \mathrm{kg}$ feed $^{\mathrm{f}}$ $190 \mathrm{~g} / \mathrm{kg}$ feed $^{\mathrm{f}}$ Mid lactation (5-8 wk) $2600 \mathrm{Kcal} / \mathrm{kg}$ feed $^{\mathrm{f}}$ $180 \mathrm{~g} / \mathrm{kg} \mathrm{feed}^{\mathrm{f}}$

${ }^{a}$ Mandal et al. (2005); ${ }^{b}$ Salah et al. (2014); ${ }^{c}$ Luo et al. (2004); ${ }^{d}$ Nsahlai et al.(2004a); ${ }^{e}$ Nsahlai et al.(2004b); ${ }^{\mathrm{f}}$ Gorgulo et al. (2003)

\section{Performnaces Target in intensive production system}

Intensive and export-oriented goat production system required that a certain target of technical parameters of goats should be clearly defined for any stage of physiological states. Since breeding enterprise is the most crucial segment of the animal supply chains in providing good quality of animal stock sustainably, the technical parameters of breeding does is essential to achieved (Table 3). The amount of animal stock produced will depend on the reproduction and production index of the breeding goats, and these parameters are strongly influenced by the feeding system. In order to achieved the maximum genetic 


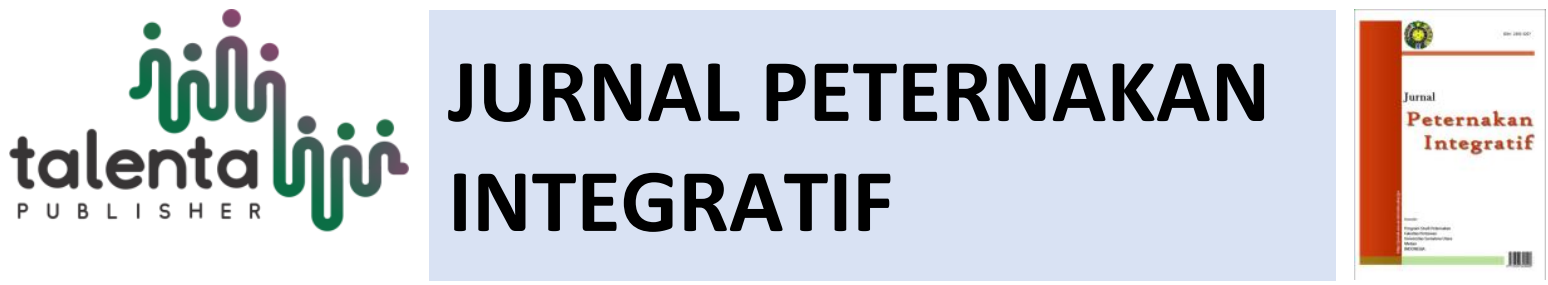

potential of the goat it is required that the nutrition of the animals is provided properly and feeding strategy should be allocated for each physiological state in order to obtained maximum efficiency of feed utilization.

Tabel 3.Typical performances of Boerka (Boer x Kacang) goats in intensive production system

\begin{tabular}{|c|c|c|c|}
\hline Parameters & Boerka $^{\mathrm{a}}$ & $\begin{array}{c}\text { Kacang and } \\
\text { its } \\
\text { Crosses }^{\mathrm{a}, \mathrm{b}}\end{array}$ & $\begin{array}{l}\text { Ideal } \\
\text { target }\end{array}$ \\
\hline \multicolumn{4}{|l|}{ Does } \\
\hline Litter size, head & 1,56 & 1.5 & 2 \\
\hline Kidding interval, day & 268 & 260 & 240 \\
\hline Reproduction index, kid/doe/year & 1,65 & 1.30 & Maximum \\
\hline Production index, $\mathrm{kg} /$ doe/year & 1,88 & 1.50 & Maximum \\
\hline \multicolumn{4}{|l|}{ Kid } \\
\hline Daily gain (2 month post weaning), g & 150 & 60 & - \\
\hline Pre-weaning mortality, $\%$ & $<7$ & $<7$ & $<5 \%$ \\
\hline Body Weight at 30 day-weaning, $\mathrm{kg}$ & $10-14$ & $5-8$ & - \\
\hline Body Weight at 5 month, $\mathrm{kg}$ & $20-25$ & $15-17$ & Maximum \\
\hline Body Weight at 12 month, $\mathrm{kg}$ & $40-55$ & $20-25$ & Maximum \\
\hline
\end{tabular}

${ }^{a}$ Doloksaribu et al. (2005); ${ }^{a}$ Elieser (2012); ${ }^{a}$ Elieser et al. (2017) ${ }^{b}$ Ginting and Mahmilia (2008);

\section{Principal Nutrition for Pregnant dan Lactating Goats}

Nutrition in pregnant goats is used for growth and maintenance of fetal tissues (fetus, placenta) and maternal tissues (uterus and mammary gland). The nutrition adequacy for the fetal tissue depend on the maternal nutrition and the efficiency of nutrient transfer accros the placental tissue by difussion mechanism. Glucose is the main nutrient required for the metabolism mammary and uterus tissues. The mammary gland tissue then converts the glucose into lactose while the uterine tissue used the glucose as the energy source. Other potential energy sources for pregnant goats are acetate, fatty acids and keton 


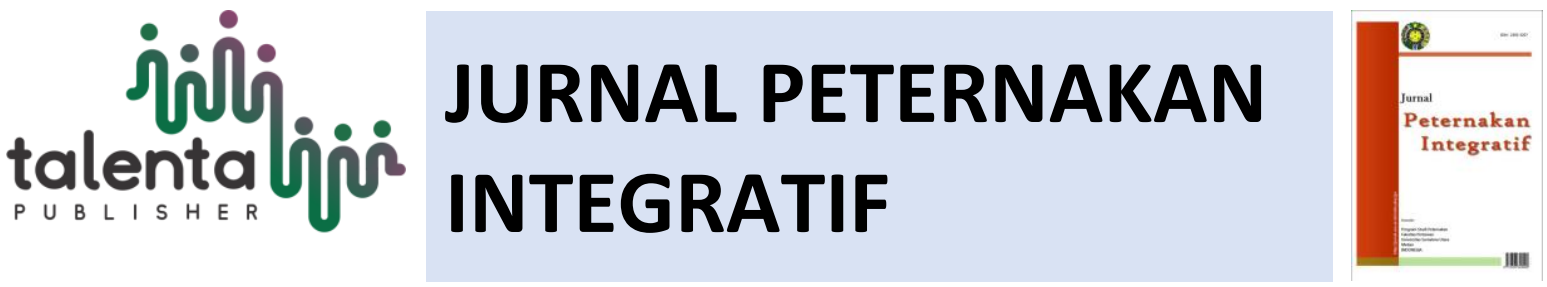

bodies. However, these substrates are not used by the fetal tissues since they could not be transported across the placenta. It is therefore that the fetal tissues totally depend on the maternal glucose. Amino acids are transported actively across the placenta and the fetal amino acid level is consistently higher than the maternal amino acids. The glucose and lactate oxidation provide only 50-60\% of the total calori needed by the fetal tissues and the remining energy (30-40\%) is provided by the oxidation of amino acids. Although the level of nutrient requirement during the early pregnancy is relatively low, the availability of these critical nutrients in the early pregnant goats will influenced their reproductive parameter [7]. Thus some nutrients that are critical during the early pregnancy are glucosa, amino acids and vitamins which are directly used as substrate for metabolism or indirectly modify the hormonal function that further influence the the maturity of the ovum, embryo development, fetal gowth, and the viability and vigor of the born kids.

During the late pregnancy, (six week prior to partus) approximately $66 \%$ of the body weight at birth of kids and $95 \%$ of the secretory mammary gland tisseue are built . Accordingly, the level of nutrient requirement during this period increase sharply. It is recommended that the requirements for energy metabolism, crude protein, Calcium $(\mathrm{Ca})$ and phosphor $(\mathrm{P})$ in the late pregnancy are approximately $1,5-$ 1,8 times the requirement for maintenance. The sufficiency and the balances of nutrients are very important for the development of fetus for maximum birth weight and for development of the mammry gland for high milk production during the lactation period. Sub-optimal nutrition during the late pregnancy put the goat in the situation of highly negative risk for fetal development, birth weight, perinatal growth, and the capability of the does for body condition recovery.

There are several amino acid that are spesifically important in the late pregnancy. Cystein for example,play important role in the maternal immunity system and seem to be the first limiting amino acid for fetal development. Other amino acid, glysine is also highly occur in the fetal tissue [7]. Hypoglycemia is a common metabolic disorder that happened in the pregnancy due to low $\mathrm{Ca}$ intake or due to low $\mathrm{Ca}$ absorption related to the hormonal function. The parathyroid hormone influence the process of convertion of vitamin D (25-hydroxy cholecalciferol) into 1,25-dihydroxycholecalciferol that stimulate the absorption of $\mathrm{Ca}$ in small intestine by enhancing the production of Ca-binding protein in the small intestine. 


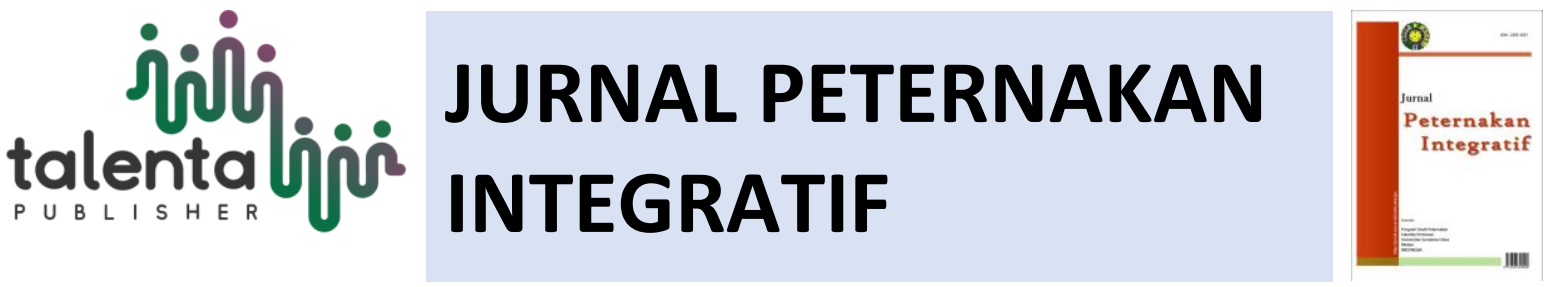

The nutrient requirements is increasing during the lactation period which are at peak level during the $3^{\text {rd }}$ and $8^{\text {th }}$ weeks of lactation period. Attempt to meet the nutrient requirement during lactation is challenged by the tendency of decreasing feed intake particularly during the early lactataion. Nutrients are required to maintained the high level of fat and protein content in the milk in the early lactation.

\section{Strategic feeding during late pregnancy and lactation}

Managing the maternal energy and protein status of goats could be performed using body condition score (BCS) as an indicator. BCS is particularly responsive to energy and protein adequacy and numerically determined by judging the fatness. The evaluation of the BCS is simple but require trained panel of individual to get accurate estimation. By maintaining BCS of 3.5 at mating the nutrition at maintenance level will be sufficient for early gestation (30-90 d), eventhough a 0.5 unit BCS reduction might be expected as the gestation progress. When the BCS at mating is too low (2.0) a higher level of nutrition would be required in order to prevent the placenta from retardation [12].

Providing nutrients only during the most critical period of breeding goats i.e. from late gestation to early lactation rather than the whole period of gestation and lactation will improve the efficiency of feed utilization and the economic of the feeding. In this case, feeding is focused on supplementing basal feed with feed supplements to increase the supply of the most critical nutrien such as glucose, amino acids, certain micro-mineral and vitamins. When feeding standard is practiced feed supplement could be selected more easily, but in the feeding budget system less choice is available, but some feed aternative could be developed (Table 4).

Table 4. Strategic supplementation for goat in feed budget system

\begin{tabular}{lccc}
\hline & Lactation & Gestation & Post-weaning \\
Feed type & $30 \mathrm{~d}$ & $90-120 \mathrm{~d}$ & $30 \mathrm{~d}$ \\
& & & \\
\hline Green concentrates $^{\mathrm{a}}$ & $0,5-1 \% \mathrm{BW}$ & $0,5 \%-1 \mathrm{BW}$ & Ad libitum \\
${\text { Synchronous P- } \mathrm{E}^{\mathrm{b}}}_{\text {Non-convensional feeds }}^{\mathrm{c}}$ & Ad libitum & Ad libitum & Ad libitum \\
\hline
\end{tabular}




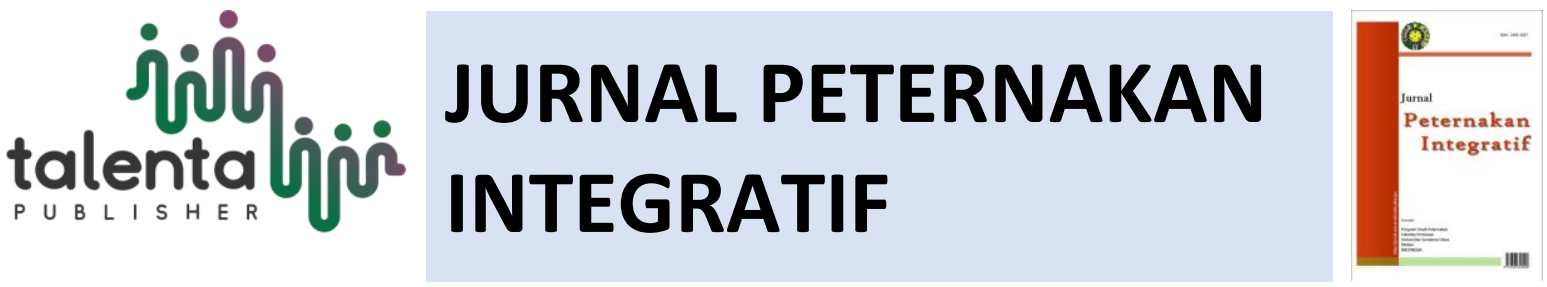

${ }^{\mathrm{a}}$ Leguminous tree- leaf (Indigofera, Leucaena, Calliandra, Gliricidia); ${ }^{\mathrm{b}}$ Synchrony of protein and energy source for rumen microbial; ${ }^{c}$ agroindustry-by products

\section{Strategic feeding for breeding goats}

Flushing refers to a feeding practice of increasing the supply of nutrition level, mainly protein and energy to doe to increase the ovulation rate and the proportion of multiple births. Improving the nutrition level during pre-ovulation will positively influence the quality and viability of the embryo. Flushing is commonly practiced approximately 2 weeks prior to breeding and is widely used in sheep. The success of flushing in goats depend on the maternal nutritional state as indicated by its BCS. It is reported that when the doe is in reasonable BCS (2.5 to 3.5) there is no response of flushing of energy and protein on kidding or conception rate (Merkel and Gipson, 2015). It is however important to note that flushing will also give no response when the doe is superovulated with exogenous gonadotrophin hormone. In this situation, increasing the energy state of the doe ( 2 x maintenance level) could result in lowering the viability of embryo. This phenomenon may be relate to the decreased oocyt quality due to the sub-optimum progesterone level during the oocyt maturing process [16]. Robinson et al. (2002) has indicated that there is a negative relationship between the nutrition level and the systemic progesterone concentration.

\section{Strategic feeding for pre-weaned kids}

The performances of pre-weaned kids is mostly determined by the ability of does to synthesize milk and milking the kids. However, pre-weaned kids are commonly starting to consume solid feed as earaly as two weeks after birth. Provided solid feed to kids earlier will promote the development of the gastro-intestinal system faster and may minimize the problem of checked growth in early weaning. Early solid feed provision (creep feeding) will potentially provide extra growth for the kid and facilitating weaning. It is suggested that the creep feed contained at least $16 \%$ protein and should be medicated with a coccidiostat.

\section{Strategic feeding for buck}

The nutrient requirements for mature male (above 2 year old) should be sufficiently provided from good quality forages with standard feed intake level. Young male buck $(<2$ years $)$ required higher level of nutrition and may need some feed concentrate to stimulate growth and to reach standard body weight. Feeding system should provide the young buck to get a BCS of 3 to 4 and feeding concentrate feed at 


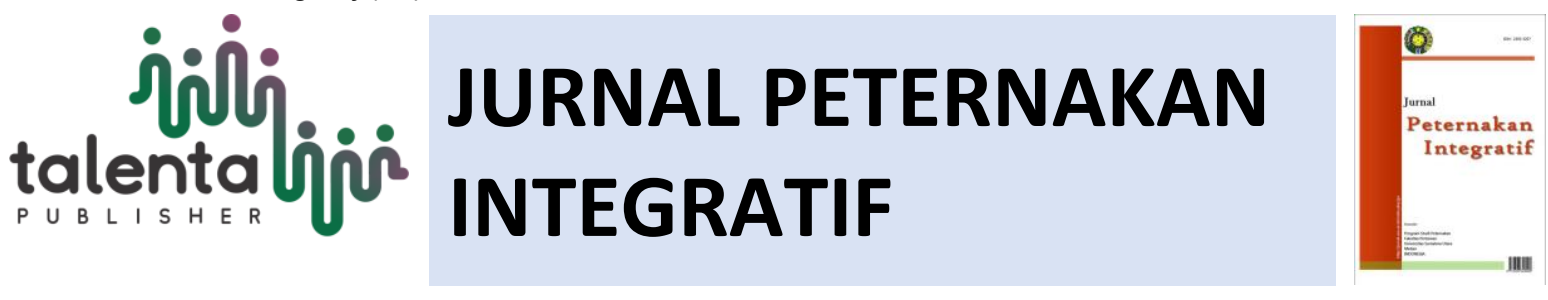

0.10 to $0,25 \%$ body weight will be able to maintain this BCS to prevent the male goat from urinary calculi. The BCS of the mature male need to be monitored every 2 to 3 month befor use for mating.

\section{Complete feed for intensive goat production}

Feeding technology such as complete feed in various physical forms (pellet, block; mixed) provide alternative feeding practice in intensive goat production system. Complete feed has been shown to be better compared to convensional feeding where thas basal and feed concentrate are fed separately [23]. Minimum feed ingredients selection and so more homogenous intake and more stable of rumen fermentation could be expected in complete feed system. Complete feed is becoming more accepted in intensive goat production system. This feed technology could improve the efficiency of feed utilization particularly of the non-conventional feeds through increased feed intake and feed digestibility (Table 5).

Table 5. Benefits of complete feed to support intensive feeding system for goat production

\begin{tabular}{lll}
\hline Feed and nutrition merits & \multicolumn{1}{c}{$\begin{array}{c}\text { Effect on } \\
\text { feed utilization }\end{array}$} & \multicolumn{1}{c}{$\begin{array}{c}\text { Impact on } \\
\text { the feed utilization }\end{array}$} \\
\hline Feed intake & ${\text { Increasd feed intake }{ }^{\mathrm{a}, \mathrm{b}}}$ & $\begin{array}{l}\text { More flexible in feed utilization; } \\
\text { improved feed efficiency }\end{array}$ \\
Rumen fermentation & $\begin{array}{l}\text { Stable } \mathrm{pH}, \text { substrate } \\
\text { synchrony,microbial protein }{ }^{\mathrm{c}}\end{array}$ & $\begin{array}{l}\text { Less feed loss; improved feed } \\
\text { efficiency }\end{array}$ \\
Digestibility & Increased digestibility $^{\mathrm{d}}$ & Less feed loss;improve digestion \\
& & efficinecy \\
Feedstuff & Feed preservation; Feed logistics & More flexible feed management \\
management/handling & & \\
\hline
\end{tabular}

${ }^{\mathrm{a}}$ Sharma et al. (2006); ${ }^{\mathrm{b}}$ Babu et al. (2013); ${ }^{\mathrm{c}}$ Mudgal et al. (2012), ${ }^{\mathrm{d}}$ Saijpul et al. (2016)

Complete feed in the pellet form will improve the benefit of practicing complete feed and more effective in preventing the potential occurrence of metabolic disorder due to increase intake of certain substrat (Østergaard dan Grohn, 2000). Basal feed that is functioning as fibre source for goats could be forages such as grass (Brachiaria ruziziensis) or legumes (I.zollingeriana) (Ginting et al. 2018) and other plant residues such as palm oil fronds (Ginting et al. 2017). This study indicated that complete feed was 


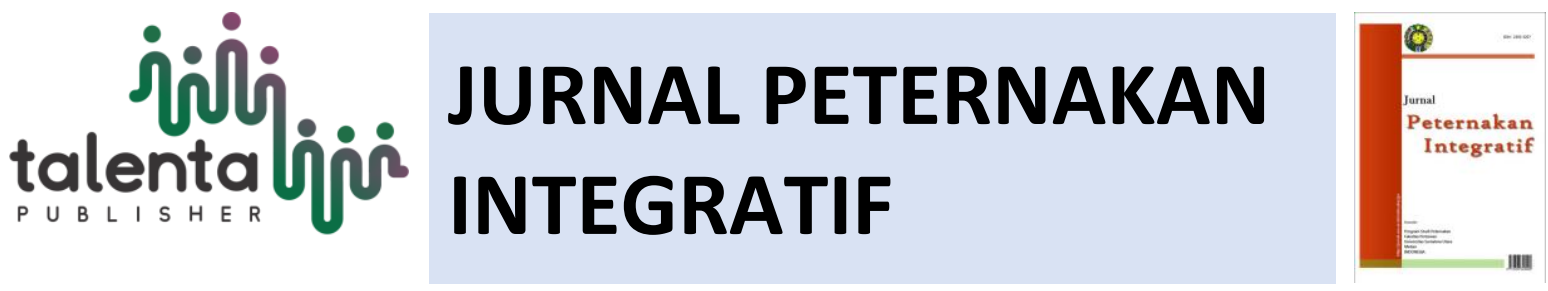

accetpted by Boerka goats with good feed intake (1100 g DM per day) with mean body weight of $25 \mathrm{~kg}$ or equivalent to $56,5 \mathrm{~g} / \mathrm{kg} \mathrm{BB}$. Mean gain was achieved at $115 \mathrm{~g} / \mathrm{d}$. Haigh level of feed intake has also been reported by Pi et al. (2005).

\section{Conclusion}

There is large potential for exporting meat goats and so gaining more economic benefit from raising this animal. There are several constraints faced by the goat producers or traders in fulfilling the potential demand of the market. Developing a more intensive goat production system is urgently needed in order to increase the capacity of the stock supply while at the same time the goat population is developing to make the system sustainable in the long term. Feeding system and feed management is aldo critical to be developed intensively to be more well adaptive. Feed budget or feeding standard are some alternative feeding approach for intensive goat production system and feeding strategy and feed technology are important in optimizing the level of productivity of goats during each phase of its life cycle and production.

\section{References}

[1] Ashworth, C.J., and C. Antipatis. 2001. Micronutrient programming of development throughout gestation. Reproduction 122: 527-535.

[2] Babu, A.S., D.S. Rao, Y.R. Reddy and D. Nagalaksmi. 2013. Effect of feeding various roughage based processed complete diets on intake and nutrien utilization in ram lambs. Indian $\mathrm{J}$. Nutr. 30:252-255

[3] Diwyanto, K., A. Priyantini dan I. Inounu. 2004. Prospek dan Arah Pengembangan Komoditas Peternakan: unggas, sapi dan kambing-domba. Wartazoa 15:11-25

[4] Doloksaribu,M., S. Elieser, F. Mahmilia, dan F.A. Pamungkas. 2005. Produktivitas Kambing Kacang Pada Kondisi Dikandangkan : 1. Bobot Lahir, Bobot Sapih, Jumlah Anak Sekelahiran Dan Daya Hidup Anak Pra Sapih. Seminar Nasional Teknologi Peternakan dan Veteriner. Bogor, 12 13 September 2005. Pusat Penelitian Dan Pengembangan Peternakan.

[5] Elieser.S., 2012. Performan Hasil Persilangan Antara Kambing Boer Dan Kacang Sebagai Dasar Pembentukan Kambing Komposit. Disertasi. Program Pascasarjana Fakultas Peternakan Universitas Gadjah Mada. Yogyakarta.

[6] Elieser. S., et al., 2017. Penelitian Pembentukan Bibit Kambing Potong Unggul Dengan Metode Persilangan Antara Kambing Boer dan Kambing Lokal dan Teknologi Reproduksi Loka Penelitian Kambing Potong. Pusat Penelitian dan Pengembangan Peternakan Badan Penelitian dan Pengembangan Pertanian Kementerian Pertanian. Laporan Kegiatan Tahun 2016.

[7] Ginting S.P., and F. Mahmilia. 2008. Kambing 'Boerka': Kambing tipe pedaging hasil persilangan Boer dengan kambing Kacang. Wartazoa 18:117-127 


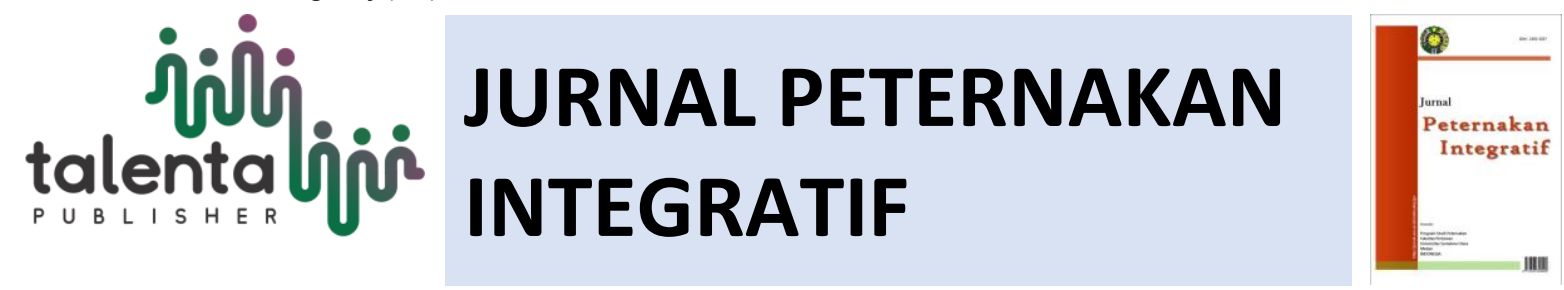

[8] Ginting, S.P., K. Simanihuruk, Antonius dan A. Tarigan. 2017. Growth and feed utilization of Boer $\mathrm{x}$ Kacang crossbred goats offered total mixed rations of diferent protein and energy levels. JITV 22: $188-195$.

[9] Goetsch, A.L., G. Detweiler, T. Sahlu, R. Puchala and L.J. Dawson. 2001. Dairy goat performancewith different dietary concentrate levels in late lactation. Small Rum. Res. 41:117-125

[10] Gorgulu, M., O. Guney, O. Torun, O. ozuyanik and H.R. Kutlu. 2003. An alternative feeding systemfor dairy goats: Effects of free choice feeding on milk yield and milk composition oflactating suckling Damascus goats. J. Anim. Feed Sci. 12: 33-44

[11] Haenlein, G.F.W and M.A. Abdellatif. 2004. Trends in small ruminant husbandry and nutrition and specific reference to Egypt. Small Rumin. Res. 51: 185-200.

[12] Heasman, L., L. Clarke, T.J. Stephenson and M.E. Symonds (1999). The influence of maternalnutrien restriction in early to mid-pregnancy on placental and fetal development in sheep.Proc. Nutrition Society 58: 283-288.

[13] Kelly, R.W. 1992. Nutritional dan placental development. Proc. Nutrtion Society of Australia. 17: 203- 211.

[14] Luo, J., A.L. Goestch, T. Sahlu, I.V. Nsahlai, Z.B. Johnson, J.E. Moore, M.L. Galyean, F.N. Owensand C.L. Ferrel. Prediction of metabolizing energy and protein requirements formaintenance, gain of preweaning, groeing and mature goats. Small rum. Res. 53: 231-252.

[15] Mandal , A.B., S.S. Paul, G.P. mandall, A. Kannan and N.N. Pathak. 2005. Deriving nutrient requirement of growing Indian goats under tropical condition. Small rum. Res. 58: 201-217.

[16] McEvo, T.G., J.J. Robinson, C.J. Ashworth, J.A. Rooke and K.D. Sinclair. 2001. Feed anf forage toxicant affecting embryo survival and fetal development. Theriogenology 55: 1134-129.

[17] Merkel R.C., and T.A.Gipson. 2015. Meat Goat Production Handbook. (R.C. Merkel, T.A. Gipson and T. Sahlu eds.). American Institute for Goat Research Langston University.

[18] Mudgal, V., M.K. Mehta and A.S. Rane. 2012. Effect of feeding lentil (Lens culmaris) straw based ration on nutritional utilization, rumen fermentation and growth and economics in Baebari kids. Indian. J. Anim. Nutr. 31: 340-344

[19] Noor, Y.G., dan R. Hidayat. 2017. Menggerakkan produksi ternak kambing domba berorientasi ekspor Pros. Seminar Nasional Teknologi Peternakan dan Veteriner, Puslitbang Peternakan. Hal 37-47.

[20] Nsahlai, I.V., A.L. Goetsch, J. Luo, Z.B. Johnson, J.E. Moore, T. Sahlu, C.L. Ferrel, M.L. Galyeanand F.N. Owens. 2004a. Metabolizable energy requirement of lactating goats. Small Rum.Res. 53: 253-273

[21] Nsahlai, I.V., A.L. Goetsch, J. Luo, Z.B. Johnson, J.E. Moore, T. Sahlu, C.L. Ferrel, M.L. Galyeanand F.N. Owens. 2004b. Metabolizable protein requirement of lactating goats. Small Rum.Res. 53: 327-337

[22] Østergaard, S., and Y.T. Grohn. 2000. Concentrate feeding, dry-matter intake, and metabolic disorder in Danish dairy cows. Livest.Prod. Sci. 65: 107-118.

[23] Pi, Z.K., Y.M. Wu and J.X. Liu. 2005. Effect of pretreatment and palletization on nutritive value of rice straw-based total mixed ration, and growth performance and meat quality of growing Boer goats fed on TMR. Small Rumin. Res. 56: 81-88.

[24] Robinson, J.J., J.A. Rooke and T.G. McEvoy. Nutrition for conception and pregnancy. 2002. In:M. Freer and H. Dove (Eds.) Sheep Nutrition. CABI Publishing in association with CSIROPublishing. $189-212$. 


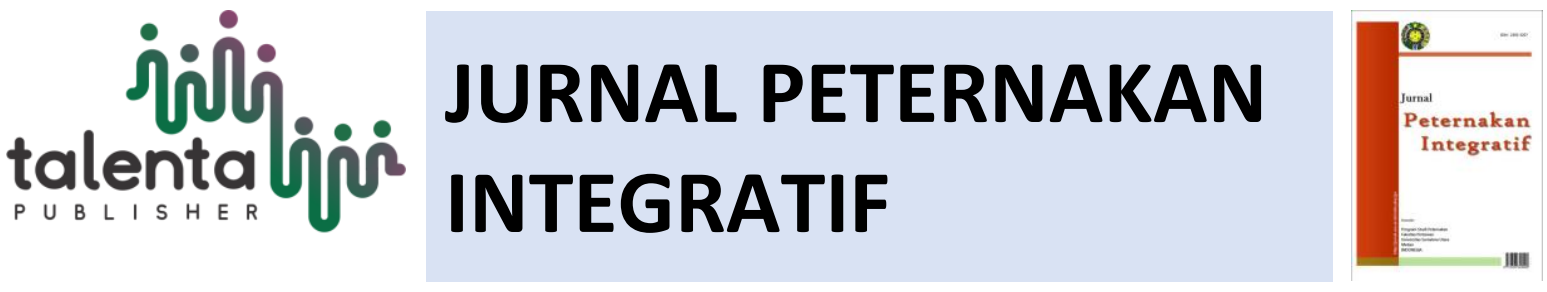

[25] Sahlu T., A.L. Goetsch, J. Luo, I.V. Nsahlai, J.E. Moore, M.L. Galyean, F.N. Owens, C.L. Ferrel,and Z.B. Johnson,. 2004. Nutrient requirements of goats: developed equations, otherconsiderations and future research to improve them. Small Rum.Res. 53: 191-219

[26] Salah, N., D. Sauvant and H. Archimede. 2014. Nutritional requirements of sheep, goats andcattle in warm climates: a meta-anaysis. Animal: 8:9, 1439-1447.

[27] Sharma, V., G.R. Purohit, R.S. Arya and M. Harsh. 2006. Evaluation of some complete rations in sheep incorporating unconvensional feed resources of arid zone of India. Anim. Nutr. Feed Technol. 6:135-141.

[28] Saijpul, S. C., and A.L. Sani. 2016. Effect of concentrate feed and crop residue based complete feed block on nutrien utilization, growth and physiological performance of Beetal kids under stallfed condition. Anim. Feed Technol. 16:71-81

[29] Sykes, A.R., and Russel, A.J.F. 2000. Defisienscy of mineral macro-element. In: Martin W.B. andI.D. Aitken (Eds.) Diseases of Sheep., $3^{\text {rd }}$ Edn. Blackwell Science, Oxford, pp. 318-331. 